\title{
UH researcher files transgenesis suit
}

A researcher from the laboratory responsible for the first mouse-cloning experiments (Nature, 394, 369, 1998) is suing the University of Hawaii (UH) on the grounds that it licensed without his consent the rights to a series of technologies that he developed and claims he owns. In late July, Anthony Perry began litigation against UH to try and reclaim the rights which were licensced to ProBio, a biotechnology company based in Honolulu. Perry now plans to exploit the technology through a firm he recently cofounded.

Among the technologies in question is a new method of mammalian transgenesis, a method of microinjection that it is believed will allow the insertion of larger sized pieces of DNA into oocytes than pronuclear injection, the method most widely used to make transgenic animals. The technique was reported in Science in May $(284,1180)$.

Perry's suit is partly based on the fact that he wasn't a UH employee during the time he developed the technique in 1997, but was on a European Molecular Biology Organization Fellowship at UH in the laboratory of Ryuzo Yanagimachi. One of his coworkers, Teruhiko Wakayama, who cloned the Honolulu mouse, was on a fellowship from Japan and also not a UH employee at the time.

Last year, UH struck a research agreement involving work from Yanagimachi's laboratory with an affiliate of ProBio, which assigned the rights, with an option to negotiate a license, to ProBio (Nature Biotechnology, 16, 797, 1998). The current dispute results from the university licensing the novel transgenesis method and three other technologies allegedly without Perry's consent.

Alan Teramura, UH senior vp for research, is critical of Perry. In an opinion piece in the Honolulu Advertiser (Aug. 1, 1999), Teramura claims that Perry "urged that the university exclusively license the technology to ProBio...."

Perry admits that he initiated and, at first, supported the idea of commercializing the technology through ProBio, consenting to a preliminary agreement. He signed a power of attorney for UH's attorney to process a provisional patent application for transgenesis. However, he says that he did not see the final agreement with ProBio until May, five months after it was signed. Perry insists that neither he nor Wakayama were involved in negotiating the contract, and that the agreement is "incredibly bad."

Myrna Watanabe is a freelance writer working in Patterson, NY.
Perry now questions UH's choice of company, claiming he is concerned that the CEO of ProBio, Laith Reynolds, doesn't really understand the technologies he is licensing; he points out that ProBio has no scientific advisory board. Moreover, he is uncomfortable with the way ProBio is funding the deal: ProBio has borrowed $\$ 750,000$ from the State of Hawaii Department of Business, Economic Development \& Tourism for working capital and to pay licensing fees to the UH. And, according to Teramura, ProBio is currently behind in its payments to $\mathrm{UH}$.

Perry, who insists, "I never signed a contract of employment [with UH]; I never signed my rights to intellectual property in general or intellectual property specifically," has asked for a judgment as to who owns the technology.

However, Teramura argues that "intellectual property that's conceived and developed at the university belongs to the university." $\mathrm{He}$ does concede that Perry "had not signed the assignment of the patent to the university," but says "we don't need it until later in the process." Teramura adds that, "Unfortunately, much of all universities' procedures and what they're doing about intellectual property have been on the fly for the last 10 years or so." UH is reportedly deciding whether to countersue.

In the meantime, Perry, Wakayama, and a Honolulu City councilman, John Henry Felix (chairman emeritus of the board of the Salk Institute), have formed their own company, BiogeneSys International (Honolulu), to commercialize the two researchers' technologies. "Unfortunately, these individuals just smell money," says Teramura.

According to Teramura, Perry's attorney declined to accept binding arbitration in the matter. "When potential for large dollars is there, it brings out the worst in people," laments Teramura. "The irony I find in this whole thing," he adds, "is our IP policy is that we actually give the inventors $50 \%$ of the royalties."

Myrna Watanabe

\section{Director bids aloha, storm brews over UH NSF institute}

The transgenesis dispute comes at a time when the University of Hawaii's (UH) practices are already in question. As the Marine Bioproducts Engineering Center (MarBEC) prepares for its first annual review by the National Science Foundation (NSF) at the end of this month, the recent departure of Oskar Zaborsky as director of MarBEC has been touted by Honolulu newspapers as another entry in the university's long list of misdeeds and missed opportunities.

The saga began in 1997 when Zaborsky, with the support of UH deans and President Kenneth Mortimer, applied for an NSF award to set up a marine biotechnology center on UH's flagship campus in Manoa (Honolulu).

Zaborsky was key to the success of both the early-stage planning and establishing partnerships. Through his experience and links with the National Academy of Sciences, NSF, universities, and private industry, Zaborsky formed a partnership with University of California, Berkeley. He was also instrumental in attracting other collaborators and advisors, including the USDA's Eastern Regional Research Center, Argonne National Laboratories, and the Edgewood Research Development and Engineering Center of the US Army.

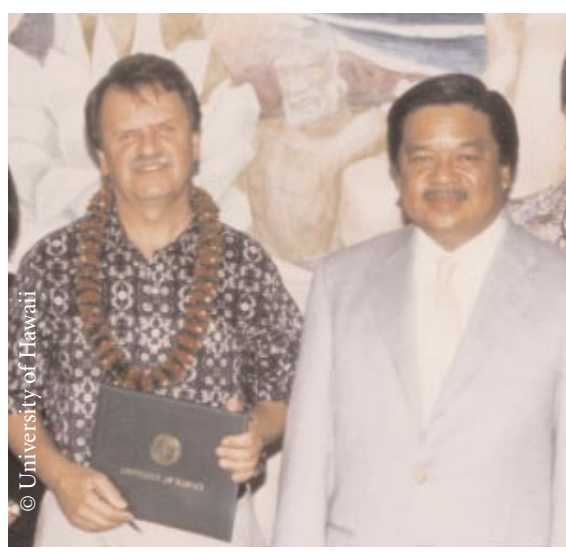

Former MarBEC director, Oskar Zaborsky (left) and Hawaii Governor, Ben Cayetano.

Furthermore, about 20 firms agreed to become partners if the center was funded.

The application to NSF was successful, and UH was awarded a \$12.4 million, fiveyear commitment from NSF to set up and run MarBEC. The first version of the cooperative agreement was sent to $\mathrm{UH}$ to sign in July 1998.

Cheryl Cathey, NSF program director for the Education and Centers Division, who oversees NSF's agreement with MarBEC, explains that the NSF must 